\title{
IPCC report under fire
}

\section{Critics attack panel's lack of specific guidance on how countries should lower emissions.}

\section{BY QUIRIN SCHIERMEIER}

$\mathrm{I}$ s the Intergovernmental Panel on Climate Change (IPCC) losing steam? It is tackling a global problem that remains as urgent as ever. But the expert body's latest report, released on 13 April and focused on mitigation, has left many climate experts and policy analysts unsatisfied.

The document, a policy summary prepared by Working Group III of the IPCC, is the third instalment of the IPCC's Fifth Assessment Report. It follows reports on the science of climate and the impacts of climate change, released in the past few months. Compiled by hundreds of lead and reviewing authors over several years, the report warns that without substantial policy and technology changes, the world is heading towards dangerous temperature rises. Its focus is therefore on the technological and economic options for stabilizing atmospheric greenhouse-gas concentrations at acceptable levels.

"The analysis is all there," says Bob Ward, a policy director at the London School of Economics' Grantham Research Institute on Climate Change and the Environment, who was not involved in the report. "Now leaders must get to grips with that message."

But others find the key conclusions unsurprising and short of detail. They say that the document sidesteps any hint of what specific countries, or groups of countries, should do to move towards clean energy systems. In particular, critics are concerned about the large emitters - China, the United States, the European Union and India, which together account for more than half of global carbon dioxide output.

"The core message is that emissions need to go down, and that the costs are affordable," says Glen Peters, a climate-policy analyst at the Center for International Climate and Environmental Research - Oslo (CICERO). "But the big-picture stuff is not very helpful for decision-makers in specific countries, and

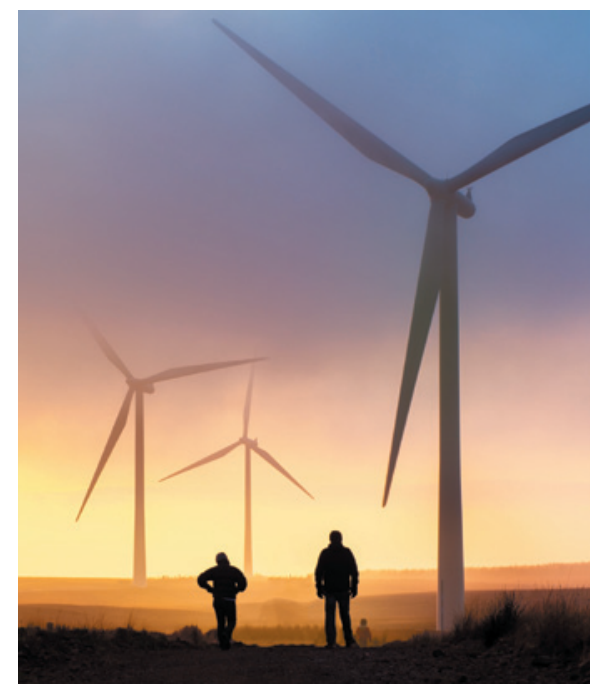

Renewable-energy systems are improving globally.

it is pretty much useless for the international climate-negotiation process."

Others agree. Steve Rayner, who studies policy frameworks for climate change at the University of Oxford, UK, says: "The headline findings are predictable - and not very exciting. The all-too-familiar-sounding bottomline messages don't seem to justify the huge effort involved."

The report, released at a packed press conference in a Berlin hotel, details how annual emissions have increased from 27 gigatonnes (Gt) of $\mathrm{CO}_{2}$ equivalent in 1970 to $49 \mathrm{Gt}$ in 2010 (see 'Who emits what?'). Emissions may now have reached more than $52 \mathrm{Gt}$ per year. The report adds that to have a $50 \%$ chance of keeping the global surface-temperature increase below the UN target of $2{ }^{\circ} \mathrm{C}$, humans must not release more than an additional $1,550 \mathrm{Gt}$ of greenhouse gases before 2100 . At current rates, that limit will be exceeded before 2050 .

The working group also warns that developed countries' emissions targets for 2020 agreed at a 2010 climate summit in Cancun,
Mexico - are inconsistent with the $2^{\circ} \mathrm{C}$ ceiling which was set at the same summit. "Meeting this goal would require further substantial reductions beyond 2020," the report finds.

The IPCC also acknowledges that the renewable-energy industry is making substantial gains in performance and cost reductions. But it notes that growing global energy demand and an increase in coal's share of the global fuel mix in recent years threaten to thwart mitigation efforts.

"Irrespective of precise emissions targets, we have to start to bring the mitigation train on track by fundamentally up-scaling lowcarbon forms of energy around the world," says Ottmar Edenhofer, co-chair of the IPCC's mitigation group. Nuclear power and environmentally safe geoengineering technologies, such as the removal of atmospheric $\mathrm{CO}_{2}$ and the capture and storage of carbon emissions, will all need to be considered, he says.

Some researchers have long argued for a more pragmatic and diversified approach to climate change. For example, one group wrote in a policy paper in 2010 that fostering technological progress while focusing on poverty reduction - an estimated 1.5 billion people have no access to electricity - might ultimately prove more effective than international treaties such as the expired Kyoto Protocol on climate change (G. Prins et al. The Hartwell Paper; LSE, 2010).

Robert Stavins, an environmental economist at Harvard University in Cambridge, Massachusetts, and a lead author of the IPCC report, emphasizes that the greatest challenges in mitigating the effects of climate change will be political, not technological.

Most critics agree that the IPCC, despite not having a remit to prescribe policies, has managed to strengthen the links between science and politics. "The process forces policy-makers to really engage with the science underlying climate change," says Peters. "Given the scale of the problem we're facing, that's good to know." -
Anthropogenic greenhouse-gas emissions reached 49 gigatonnes of carbon dioxide equivalent in 2010 . Here, the total is broken down by economic sector and electricity and heat production*.

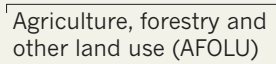

Other energy $9.6 \%$
INDIRECT $\mathrm{CO}_{2}$ EMISSIONS FROM ELECTRICITY AND HEAT PRODUCTION

\begin{tabular}{llr}
$\begin{array}{ll}\text { Buildings } \\
12 \%\end{array}$ & $\begin{array}{l}\text { Industry } \\
11 \%\end{array}$ & $\begin{array}{r}\text { Energy } \\
1.4 \%\end{array}$ \\
& & \\
AFOLU & Transport & \\
$0.9 \%$ & $0.3 \%$ & \\
\hline
\end{tabular}

*Numbers do not add up to $100 \%$ owing to rounding. 